\title{
Spindle Cell Carcinoma of the hypopharynx: a case report
}

\author{
Dillu Ram Kandel \\ Department of ENT, BP Koirala Institute of Health Sciences, Dharan, Nepal.
}

Correspondence

Dr. Dillu Ram Kandel

Department of ENT, BP Koirala

Institute of Health Sciences,

Dharan, Nepal.

\section{Email:}

drdrkandel@gmail.com

DOI: http://dx.doi.org/10.3126/

jemsn.v14i1.19241

Orcid ID: orcid.org/0000-00019462-0101

Article received: Feb $19^{\text {th }} 2018$

Article accepted: Mar $26^{\text {th }} 2017$

\begin{abstract}
Spindle cell carcinoma of hpopharynx is a rare pathology. It is a poorly differentiated variant of squamous cell carcinoma and morphologically resembles sarcoma. This is a disease of old age. It is usually associated with smoking and alcohol abuse. When it is associated with history of radiation exposure, it behaves more aggressively. Surgery is considered as the main modality of treatment and adjuvant radiotherapy is added when necessary. Here we present a case of 79 year old male with spindle cell carcinoma of right piriform fossa with 2-month history of progressive dysphasia and hoarseness that has been affecting his ability to speak and swallow with history of weight loss and past history of radiotherapy. So possibility of spindle cell carcinoma of the hypopharynx should be considered in an old patient with rapidly developing swelling of the hypopharynx with past history of radiation exposure. As it is a highly aggressive disease it should be treated timely and more aggressively to prolong the survival of the patient.
\end{abstract}

Key words: Spindle cell carcinoma; piriform fossa; radiotherapy

Citation: Kandel DR. Spindle Cell Carcinoma of the hypopharynx: a case report. JCMS Nepal. 2018;14 (1):59-61.

\section{INTRODUCTION}

Spindle cell carcinoma presents less than $3 \%$ of all head and neck malignancies of epithelial origin. ${ }^{1}$ Spindle cell carcinoma of the larynx is a rare tumor and comprises $2 \%$ to $3 \%$ of all laryngeal cancers. ${ }^{2}$ Spindle cell carcinoma (SPC) consist of elongated (spindle) cells of epithelial origin, representing an unusual form of poorly differentiated squamous cell carcinoma but morphologically these resemble a sarcoma. ${ }^{3}$ Squamous cell carcinoma is the most malignant carcinoma of the larynx, and spindle cell (sarcomatoid) tumor is considered a highly malignant variant of squamous cell carcinoma. .

\section{CASE DESCRIPTION}

A 79 year-old male presented to our OPD with 2month history of progressive dysphasia and hoarseness that has been affecting his ability to speak and swallow. He gave history of weight loss also because of difficulty in swallowing. He also gave history of smoking. His past history included radiotherapy for neck swelling which was found to be Hodgkin's lymphoma on incisional biopsy of the neck swelling.

On clinical examination he had thin built. Neck examination showed minimal bulge over right superolateral part of the neck. On fibroptic examination of the larynx a pale proliferative mass was present. It was involving lateral and medial walls of the involved right pyriform fossa. There was bulge in the false vocal cord due to mass involving medial wall of pyriform fossa. Right vocal cord had decreased mobility.

Contrast enhanced Computer tomography showed discrete to diffusely enhancing exophytic mass in right piriform fossa involving both medial and lateral wall. Supraglottis appeared normal. However no any cartilage destruction appreciated. There were no any adenopathy in the neck. Nasopharynx, oropharynx, submandibular gland, parotid gland and 


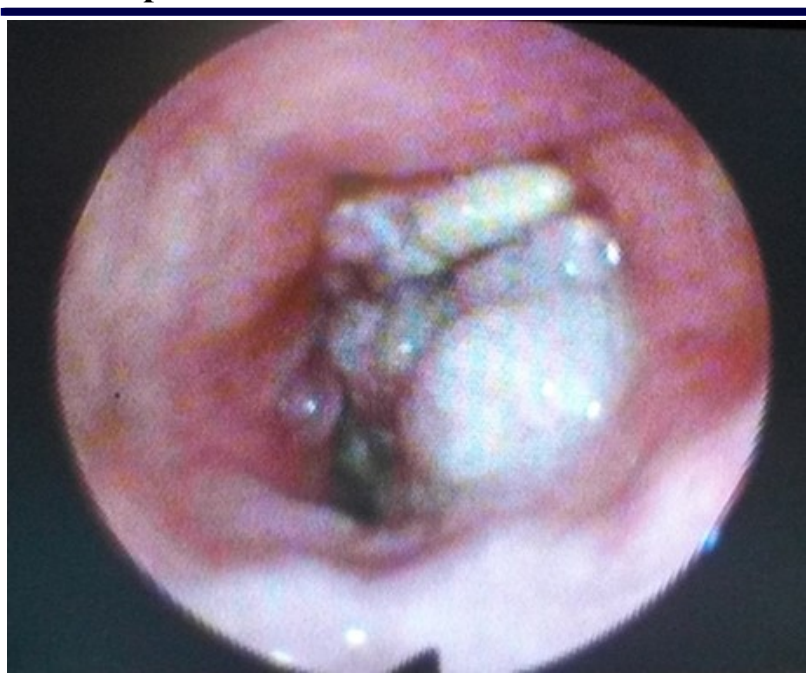

Fig.1 Endoscopic view of the spindle cell carcinoma right PFS.

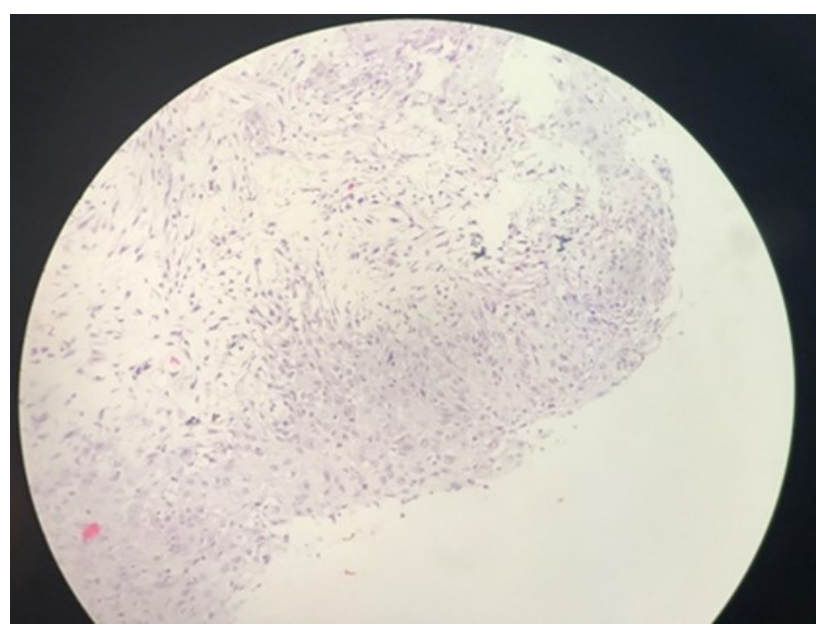

Fig. 2.H\&E (40X) section showing areas of ulceration with full thickness dysplasia

thyroid gland were normal.

By doing direct laryngoscopic examination under general anaesthesia biopsy is taken from the mass. Biopsy was done with debulking intent to relieve from the symptoms as well. It was quite avascular mass. The histopathology came to be inconclusive. So again complete debulking was done. The histopathology report came to be spindle cell carcinoma of right pyriform sinus. Patient was then sent for further management in cancer centre where he received definitive radiotherapy. But patient died after four months due to recurrence.

\section{DISCUSSION}

There are various terminologies for biphasic tumours of the head and neck like carcinosarcoma, sarcomatoid carcinoma, SPC, metaplastic carcinoma, or pleomorphic carcinoma. These

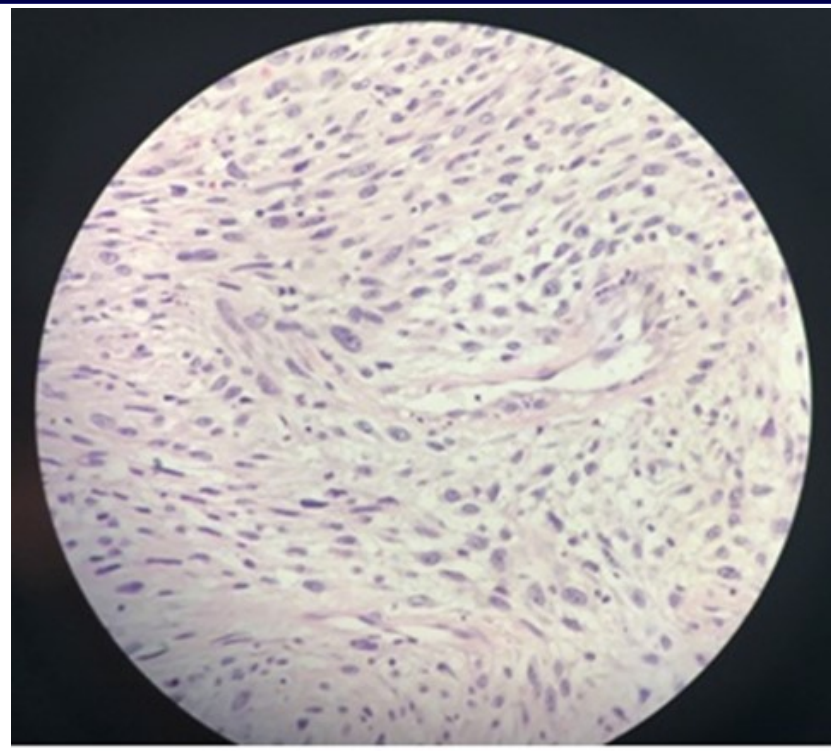

Fig.3.H\&E (400X) section of spindle cell carcinoma revealing spindle shaped cells showing pleomorphism, elongated hyperchromatic nucleus with frequent mitotic figures.

tumours are commonly seen in middle aged to elderly males. Similarly alcohol and tobacco smoking has been found to be associated with this tumour. Prior radiation exposure has also been found to be associated but it was not considered as causal factors. ${ }^{4,5}$ But it has been found that whenever it is associated with radiation exposure the disease is found to be more aggressive. Similar to this finding in our case also there was history of radiation exposure and the disease was also found to be more aggressive causing the death of the patient in spite of treatment by surgery and radiotherapy.

In the larynx majority arises in the glottis from the true vocal cord and anterior commissure. ${ }^{4,6}$ In our case it arises from the right pyriform sinus.Other than larynx other common site are oral cavity affecting the lower lips, tongue and buccal mucosa. ${ }^{7}$ The outcome in SPC is said to be favourable as compared to other sites in the upper aerodigestive tract. However other factors like history of exposure to radiation may make it more aggressive disease.

The histogenesis of spindle cell carcinoma is controversial and three major pathogenetic theories have evolved: the tumour (1) represents a "collision tumour"(carcinosarcoma); (2) is a squamous cell carcinoma with an atypical reactive stroma (pseudosarcoma); or (3) is of epithelial origin, with "dedifferentiation" or transformation to a spindle cell morphology (sarcomatoid carcinoma). ${ }^{8}$ While 
the lesion at the surface of the tumour is squamous cell carcinoma, the lesion in the stroma is sarcomatous, characterized by spindle cell proliferation having a whirling pattern, bizarre cells and mitosis. It has been suggested that the sarcomatous lesion originates from an epithelial element. Microscopically, it consists of squamous cell carcinoma and sarcoma-like lesions composed of spindle cells. The following three explanations of the histogenetic nature of the spindle cell component have been advocated: (1) it is not a neoplastic, but a reactive proliferation of fibroblasts and histiocytes; (2) it originates from the mesenchymal metaplasia of squamous cell carcinoma; and (3) it is a true sarcoma (i.e. fibrosarcoma of malignant fibrous histiocytoma). Immuno-histochemical study using ras oncogene p21, cytokeratin and vimentin conducted by Toda et al. $^{9}$ in 1989 which found that the spindle cell component was positive for both cytokeratin and vimentin as well as ras oncogene p21. Since electron microscopic examination showed welldeveloped desmosomes in the spindle cells, these researchers proposed that the sarcoma-like lesion was neoplastic, develops via mesenchymal metaplasia of squamous cell carcinoma. As confusion with supporting tissue neoplasm may occur in the light microscope, the use of the electron microscope in differential diagnostics is recommended.

Regarding treatment, surgery has been more frequently recommended than radiation. Many authors have felt that radiation therapy is not effective in treating these tumours and is associated with frequent recurrences. ${ }^{9}$ Surgical therapy should be primary mode of treatment and conservation operations performed when indicated, adding that neck dissections should be done primarily for supraglottic, advanced glottic and transglottic tumors. As the spindle cell carcinoma of the head and neck region may represent a more aggressive neoplasm than typical squamous cell carcinoma so prognosis of the SPC of head and neck may be worse than the conventional squamous cell carcinoma of the same region.

\section{CONCLUSION}

Spindle cell carcinoma of the hypopharynx is a poorly differentiated variant of squamous cell carcinoma and morphologically resembles sarcoma. It is highly aggressive in nature especially when it is associated with history of radiation exposure.

\section{Conflict of Interest Statement:}

\section{None Declared}

\section{REFERENCES}

1. Boamah H, Ballard B. A case report of spindle cell (sarcomatoid) carcinoma of the larynx. Case Rep Med. 2012;370204. https://doi.org/10.1155/2012/370204.

2. Völker HU, Scheich M, Höller S, Ströbel P, Hagen R, Müller-Hermelink HK, et al. Differential diagnosis of laryngeal spindle cell carcinoma and inflammatory myofibroblastic tumor - report of two cases with similar morphology. Diagn Pathol. 2007;2:1. https:// doi.org/10.1186/1746-1596-2-1. PMID: 17212821.

3. Su HH, Chu ST, Hou YY, Chang KP, Chen CJ. Spindle cell carcinoma of the oral cavity and oropharynx: factors affecting outcome. J Chin Med Assoc. 2006;69(10):47883. https://doi.org/10.1016/S1726-4901(09)70312-0.

4. Thompson LD, Wieneke JA, Miettinen M, Heffner DK. Spindle cell (sarcomatoid) carcinomas of the larynx: a clinicopathologic study of 187 cases. Am J Surg Pathol. 2002;26:153-170. https:// doi.org/10.1097/00000478-200202000-00002.

5. Goldman RL, Weidner N. Pure squamous cell carcinoma of the larynx with cervical nodal metastasis showing rhabdomyosarcomatous differentiation. Clinical, pathologic, and immunohistochemical study of a unique example of divergent differentiation. Am J Surg Pathol. 1993;17:415-21. https://doi.org/10.1097/00000478199304000-00013.

6. Barnes L. Diseases of the Larynx, Hypopharynx, and Trachea. In: Barnes L, editor. Surgical pathology of the head and neck. 3. New York: Informa Healthcare; 2009. p. 146.

7. Ellis GL, Corio RL. Spindle cell carcinoma of the oral cavity. A clinicopathologic assessment of fifty-nine cases. Oral Surg Oral Med Oral Pathol. 1980;50:523-533. https://doi.org/10.1016/0030-4220(80)90436-3.

8. Olsen KD, Lewis JE, Suman VJ. Spindle cell carcinoma of the larynx and hypopharynx. Otolaryngol Head Neck Surg. 1997;116:47-52. 59989770351-6. PMID: 9018257.

9. Toda S, Yonemitsu N, Miyabara S, Sugihara H, , Maehara N. Polypoid squamous cell carcinoma of the larynx. An immunohistochemical study for ras p21 and cytokeratin. Pathol Res Pract. 1989;185:860-6. https://doi.org/10.1016/ S0344-0338(89)80287-0. PMID:2482483. 